\title{
Prospective study on prescribing pattern of antihypertensive drugs at a tertiary care hospital
}

\author{
Vishwanath M., Murgesh J. V.*, Arpitha D., Nithiya D.
}

Department of Pharmacology, Vijayanagar Institute of Medical Sciences, Ballari, Karnataka, India

Received: 14 October 2018 Accepted: 20 October 2018

*Correspondence to:

Dr. Murgesh J. V.,

Email: javalimurgesh@ yahoo.com

Copyright: (C) the author(s), publisher and licensee Medip Academy. This is an openaccess article distributed under the terms of the Creative Commons Attribution NonCommercial License, which permits unrestricted noncommercial use, distribution, and reproduction in any medium, provided the original work is properly cited.

\begin{abstract}
Background: Hypertension is the leading non-communicable disease risk attributing to cardio vascular morbidity and mortality. Various reasons are socioeconomic, behavioural, sedentary life style, nutritional, age, obesity and poor health maintenance. A wide range of antihypertensive drugs belonging to different pharmacological classes are available alone or in combinations. Present study was done to evaluate the prescribing pattern of antihypertensive drugs at a tertiary care hospital.

Methods: A prospective, observational, non-interventional, hospital-based study was carried out in hypertensive patients attending outpatient department of General Medicine at Medical College Hospital attached to Vijayanagar Institute of Medical Sciences, Ballari. Data was collected from outpatient slip of patients in a predesigned case record form, which was analysed using descriptive statistics.
\end{abstract}

Results: Among 200 patients analysed 95 (47.5\%) were males and 105 (52.5\%) were females, with maximum number of patients falling in the age group 6170years. Among antihypertensives prescribed, amlodipine (78.5\%) was most frequently prescribed drug. Frequently used drugs for monotherapy - amlodipine (37.5\%), for two drug therapy - amlodipine + atenolol (25.5\%), and for three drug therapy - amlodipine + atenolol + telmisartan $(2.5 \%)$. WHO prescribing indicators: Average number of drugs per encounter is $2.38( \pm 1.19)$. Percentage of drugs prescribed by generic name is $76.47 \%$. Percentage of drugs prescribed from essential drug list is $97.89 \%$.

Conclusions: Present study shows current trends in prescription of antihypertensives in tertiary care hospital and their rational use. Study emphasizes need for preventive and educative measures about hypertension in population.

Keywords: Antihypertensives, Drug utilization, Hypertension, Prescription pattern

\section{INTRODUCTION}

Hypertension is defined as elevated systolic blood pressure $\geq 140 \mathrm{~mm} \mathrm{Hg}$ or diastolic blood pressure $\geq 90 \mathrm{~mm} \mathrm{Hg}$. Hypertension is the leading non-communicable disease risk attributing to cardio vascular morbidity and mortality. The overall prevalence of hypertension in India is estimated to be $29.8 \%$, about $33 \%$ urban and $25 \%$ rural Indians are hypertensive. ${ }^{1}$ It is reported to be the fourth contributor to premature death in developed countries and the seventh in developing countries. ${ }^{2}$
The various reasons for hypertension are socio-economic, behavioural, sedentary life style, nutritional, age, obesity and poor health maintenance.

Poor controlling of hypertension leads to further progression of cardiovascular complications like ischemic heart disease, heart failure, stroke, diabetes and chronic renal insufficiency. ${ }^{3}$ This situation is graver in our country since with modernization, we are trading healthy traditional diets for fatty foods; physical jobs for desk bound once and calm rural life for stressful city life. ${ }^{4}$ 
A wide range of antihypertensive drugs belonging to different pharmacological classes are available alone or in combinations. Choice of drugs for a particular patient depends on factors like efficacy, side effects and effects on other systems, cost and development of newer drugs. ${ }^{5}$ In addition to drug therapy, treatment of hypertension also includes lifestyle modifications like weight reduction, quitting smoking, eating healthy diet, reducing sodium intake, exercising regularly, and limiting alcohol consumption.

Drug utilization research was defined by WHO in 1977 as "the marketing, distribution, prescription and use of drugs in a society, with special emphasis on the resulting medical, social, and economic consequences". 6 Drug utilization research provides an insight into the drug use pattern and rational use of a drug. The study of prescribing pattern is a part of the medical audit and seeks to monitor, evaluate and if necessary, suggest modification in prescribing practices to make medical care rational and cost effective. ${ }^{7}$

Various international committees have published guidelines on the treatment of hypertension. The JNC 7 (Joint National Committee on prevention, detection, evaluation and treatment of high blood pressure) recommends the use thiazides type diuretics as the first choice when used alone or in combination with drugs from other classes of anti-hypertensive in uncomplicated essential hypertension. For $>20 / 10 \mathrm{~mm} \mathrm{Hg}$ above goal BP, combination of two agents is recommended with one of them is usually being thiazides diuretic. ${ }^{8}$ But in recent JNC 8 guidelines it do not consider diuretics as the first choice, rather, considers first-line and later-line treatments to be limited to 4 classes of medications: thiazides type diuretics, calcium channel blockers (CCBs), angiotensin converting enzyme (ACE) inhibitors and angiotensin receptor blockers (ARBs) followed by second-line and third-line alternatives included higher doses or combinations of ACE inhibitors, ARBs, thiazides-type diuretics and $\mathrm{CCBs} .{ }^{9}$

The National Institute for Health and Clinical Excellence (NICE) guideline recommend angiotensin converting enzyme (ACE) inhibitor or angiotensin receptor blocker (ARB) as first choice antihypertensive drug under 55 years, whereas calcium channel blockers (CCBs) are preferred first choice over 55 years. ${ }^{10}$

With the increasing prevalence of hypertension, there is an increase in the use of antihypertensive drugs, which can improve the quality of life and decrease the attributed morbidity and mortality. Thus, appropriate use of antihypertensive drugs, in an efficient manner is an utmost requirement. Further there is also a requirement for educating the people about hypertension and the consequences of its inadequate management, and also for implementing strategies for prevention as well. ${ }^{11}$ Hence; the present study was done to evaluate the prescribing pattern of antihypertensive drugs at a tertiary care hospital.

\section{METHODS}

This prospective, observational, non-interventional, hospital-based study was carried out for the period of three months from June 2018 to August 2018 in hypertensive patients attending outpatient department (OPD) of General Medicine at Medical College Hospital (MCH) attached to Vijayanagar Institute of Medical Sciences (VIMS), Ballari, Karnataka. This study was started after obtaining approval from the Institutional Ethics Committee.

\section{Inclusion criteria}

- $\quad$ Aged 18 years and above, of either sex, diagnosed with hypertension

- Patient with co-morbidities

- Patients who gave informed consent.

\section{Exclusion criteria}

- Pregnant females

- Unconscious patients

- Patients who were not willing to give informed consent.

After taking an informed consent from the patients, data was collected from the outpatient slips of these patients in a predesigned case record form. The case record form included demographic data like age, sex, education, disease data like diagnosis, duration, co-morbidities and drug data included the drugs prescribed both antihypertensives and non-antihypertensives. The data collected was assessed and WHO prescribing indicators were analysed.

\section{Statistical analysis}

Data was analysed using descriptive statistics namely total numbers, average, standard deviation and percentage wherever applicable.

\section{RESULTS}

\section{Age and sex distribution}

A total of 200 hypertensive patients were included in present study. Among them $95(47.5 \%)$ were males and $105(52.5 \%)$ were females.

Maximum numbers of patients were in the age group of 6170years which were $55(27.5 \%)$, followed by 51-60years which were $48(24 \%)$. Table 1 show the age and sex distribution of the patients.

\section{Antihypertensive drugs prescribed}

The antihypertensive drugs prescribed, and their frequency was analysed, among them amlodipine was the most commonly prescribed drug with a frequency of 157 
(78.5\%), followed by atenolol with a frequency of 67 (33.5\%) and enalapril with a frequency of $27(13.5 \%)$, and clinidipine was the least commonly prescribed antihypertensive with a frequency of $2(1 \%)$ (Table 2).

Table 1: Age and sex distribution of patients.

\begin{tabular}{|ll|}
\hline Gender & No. of patients $(\%)$ \\
\hline Male & $95(47.5 \%)$ \\
\hline Female & $105(52.5 \%)$ \\
\hline Total & 200 \\
\hline Age (years) & No. of patients $(\%)$ \\
\hline $18-30$ & $5(2.5 \%)$ \\
\hline $31-40$ & $23(11.5 \%)$ \\
\hline $41-50$ & $41(20.5 \%)$ \\
\hline $51-60$ & $48(24 \%)$ \\
\hline $61-70$ & $55(27.5 \%)$ \\
\hline $71-80$ & $20(10 \%)$ \\
\hline $81-90$ & $8(4 \%)$ \\
\hline Total & 200 \\
\hline
\end{tabular}

Table 2: List of antihypertensive drugs prescribed.

\begin{tabular}{|lll|}
\hline Drugs & $\begin{array}{c}\text { No. of } \\
\text { encounters }\end{array}$ & $\begin{array}{l}\text { \% age of } \\
\text { encounters }\end{array}$ \\
\hline Calcium channel blockers (CCBs) & \\
\hline Amlodipine & 157 & 78.5 \\
\hline Nifedipine & 7 & 3.5 \\
\hline Clinidipine & 2 & 1 \\
\hline Beta blockers (BBs) & & \\
\hline Atenolol & 67 & 33.5 \\
\hline Metoprolol & 14 & 7 \\
\hline Labetalol & 4 & 2 \\
\hline ACE inhibitors (ACEIs) & \\
\hline Enalapril & 27 & 13.5 \\
\hline Angiotensin receptor blockers (ARBs) & \\
\hline Telmisartan & 23 & 11.5 \\
\hline
\end{tabular}

Table 3: Antihypertensive drug therapy among patients.

\begin{tabular}{|llll|}
\hline $\begin{array}{l}\text { Therapy } \\
\text { patients }\end{array}$ & $\begin{array}{l}\text { No. of } \\
\text { patients }\end{array}$ & $\begin{array}{l}\text { \% age of } \\
\text { patien }\end{array}$ & $\begin{array}{l}\text { Most commonly } \\
\text { used drugs }\end{array}$ \\
\hline $\begin{array}{l}\text { drug } \\
\text { therapy }\end{array}$ & 113 & 56.5 & $\begin{array}{l}\text { Amlodipine }(37.5 \% \\
\text { of patients) }\end{array}$ \\
\hline $\begin{array}{l}\text { Two drug } \\
\text { therapy }\end{array}$ & 73 & 36.5 & $\begin{array}{l}\text { Amlodipine }+ \\
\text { Atenolol }(25.5 \% \text { of } \\
\text { patients })\end{array}$ \\
\hline $\begin{array}{l}\text { Three } \\
\text { drug } \\
\text { therapy }\end{array}$ & 14 & 7 & $\begin{array}{l}\text { Amlodipine }+ \\
\text { Atenolol }+ \\
\text { Telmisartan }(2.5 \% \\
\text { of patients) }\end{array}$ \\
\hline
\end{tabular}

The number of patients who were on single drug therapy, two drug therapy and three drug therapy for treatment of hypertension were noted, which shows that, out of 200 patients, 113 patients $(56.5 \%)$ were on single drug therapy, 73 patients $(36.5 \%)$ were on two drug combination therapy and 14 patients $(7 \%)$ were on three drug combination therapy (Table 3).

\section{Table 4: Utilization pattern of different} antihypertensive drugs.

\begin{tabular}{|c|c|c|}
\hline Therapy & $\begin{array}{l}\text { No. of } \\
\text { patients }\end{array}$ & $\begin{array}{l}\text { Percentage of } \\
\text { patients }(\%)\end{array}$ \\
\hline \multicolumn{3}{|l|}{ Single drug therapy } \\
\hline Amlodipine & 75 & 37.5 \\
\hline Nifedipine & 4 & 2 \\
\hline Atenolol & 11 & 5.5 \\
\hline Metoprolol & 6 & 3 \\
\hline Enalapril & 11 & 5.5 \\
\hline Telmisartan & 6 & 3 \\
\hline \multicolumn{3}{|l|}{ Two drug therapy } \\
\hline Amlodipine + atenolol & 51 & 25.5 \\
\hline Amlodipine + enalapril & 11 & 5.5 \\
\hline $\begin{array}{l}\text { Amlodipine }+ \\
\text { Telmisartan }\end{array}$ & 6 & 3 \\
\hline $\begin{array}{l}\text { Amlodipine + } \\
\text { Metoprolol }\end{array}$ & 3 & 1.5 \\
\hline Enalapril + clinidipine & 2 & 1 \\
\hline \multicolumn{3}{|l|}{ Three drug therapy } \\
\hline $\begin{array}{l}\text { Amlodipine }+ \text { atenolol }+ \\
\text { telmisartan }\end{array}$ & 5 & 2.5 \\
\hline $\begin{array}{l}\text { Amlodipine }+ \\
\text { telmisartan }+ \text { labetalol }\end{array}$ & 4 & 2 \\
\hline $\begin{array}{l}\text { Metoprolol + enalapril + } \\
\text { nifedipine }\end{array}$ & 3 & 1.5 \\
\hline $\begin{array}{l}\text { Amlodipine }+ \\
\text { telmisartan }+ \text { metoprolol }\end{array}$ & 2 & 1 \\
\hline
\end{tabular}

The utilization pattern of different antihypertensive drugs was assessed, among them; the frequently used drug for single drug therapy is amlodipine accounting for $37.5 \%$, followed by atenolol and enalapril with a frequency of $5.5 \%$ each, the frequently prescribed drugs for two drug therapy are amlodipine + atenolol which counts to $25.5 \%$, followed by amlodipine + enalapril a frequency of 5.5\%, and frequently used drugs for three drug therapy are amlodipine + atenolol + telmisartan with a frequency of $2.5 \%$, followed by amlodipine + telmisartan + labetalol accounting for $2 \%$ (Table 4 ).

\section{Co-morbidities in hypertensive patients}

The co-morbidities seen in hypertensive patients and their frequency are presented in Table 5.

Fifty five $(27.5 \%)$ of patients were having diabetes mellitus along with hypertension, which is followed by patients with ischemic heart disease which counts to $19(9.5 \%)$ and cerebrovascular accidents with frequency of $14(7 \%) .92$ $(46 \%)$ hypertensive patients had no co-morbidities. 
Table 5: Co-morbidities in hypertensive patients.

\begin{tabular}{|lll|}
\hline Co-morbidity & $\begin{array}{l}\text { No. of } \\
\text { patients }\end{array}$ & $\begin{array}{l}\text { Percentage of } \\
\text { patients }(\%)\end{array}$ \\
\hline No co-morbidities & 92 & 46 \\
\hline Diabetes mellitus & 55 & 27.5 \\
\hline $\begin{array}{l}\text { Cerebrovascular } \\
\text { accidents }\end{array}$ & 14 & 7 \\
\hline Ischemic heart disease & 19 & 9.5 \\
\hline Chronic kidney disease & 10 & 5 \\
\hline $\begin{array}{l}\text { Chronic obstructive } \\
\text { pulmonary disease }\end{array}$ & 6 & 3 \\
\hline Epilepsy & 4 & 2 \\
\hline
\end{tabular}

\section{Non-antihypertensive drugs prescribed}

The non-antihypertensive drugs that were prescribed along with antihypertensives are listed in Table 6. They are antidiabetic drugs like metformin, glimepiride, insulin, antiplatelet drugs like aspirin, clopidogrel, and diuretic furosemide, multivitamins, phenytoin, isosorbide dinitrate, ranitidine and others.

Table 6: List of non-antihypertensive drugs prescribed.

\begin{tabular}{|lll|}
\hline Drugs & $\begin{array}{l}\text { No. of } \\
\text { encounters }\end{array}$ & $\begin{array}{l}\text { Percentage of } \\
\text { encounters (\%) }\end{array}$ \\
\hline Aspirin & 36 & 18 \\
\hline Atorvastatin & 23 & 11.5 \\
\hline Metformin & 30 & 15 \\
\hline Glimepiride & 17 & 8.5 \\
\hline Insulin & 5 & 2.5 \\
\hline Furosemide & 19 & 9.5 \\
\hline Clopidogrel & 9 & 4.5 \\
\hline Isosorbide dinitrate & 9 & 4.5 \\
\hline Ranitidine & 3 & 1.5 \\
\hline Multivitamins & 9 & 4.5 \\
\hline Phenytoin & 5 & 2.5 \\
\hline Phenobarbitone & 2 & 1 \\
\hline Miscellaneous & 8 & 4 \\
\hline
\end{tabular}

\section{WHO prescribing indicators}

The WHO prescribing indicators analysed from the data are:

- Average number of drugs per encounter $=2.38$ $( \pm 1.19)$

- Percentage of drugs prescribed by generic name $=$ $76.47 \%$

- Percentage of drugs prescribed from essential drugs list $(\mathrm{EDL})=97.89 \%$

- Percentage of encounters with an injection prescribed $=4.62 \%$

A total of 476 drugs were prescribed that includes both antihypertensives and non-antihypertensives. Out of this,
$364(76.47 \%)$ drugs were prescribed by generic name and the remaining $112(23.53 \%)$ drugs by brand name (Figure 1). And $466(97.89 \%)$ drugs were prescribed from essential drugs list (EDL) and the remaining $10(2.11 \%)$ drugs were not in EDL (Figure 2).

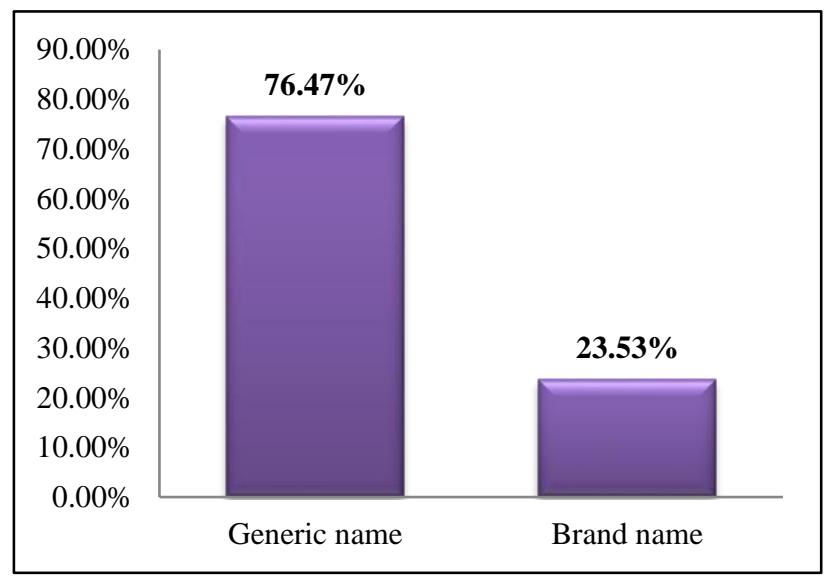

Figure 1: Drugs prescribed by generic name.

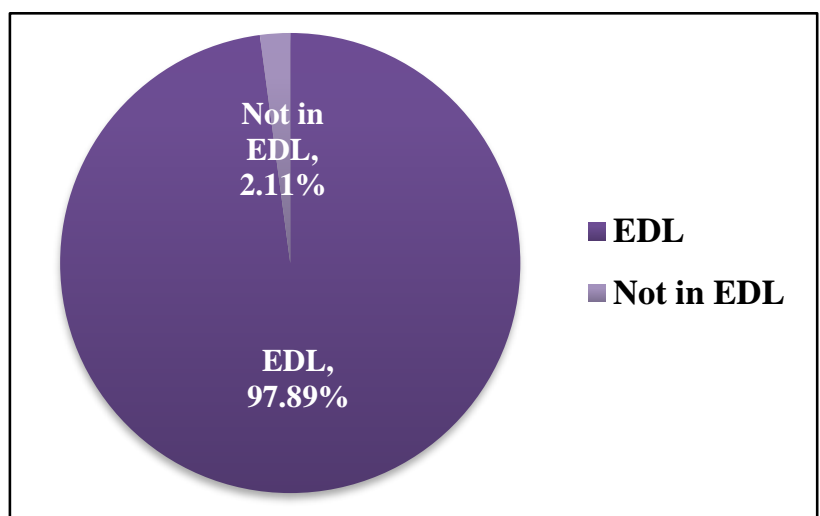

Figure 2: Drugs prescribed from essential drugs list (EDL).

\section{DISCUSSION}

The present study was carried out in hypertensive patients to evaluate the prescribing pattern of antihypertensive drugs at a tertiary care hospital. Antihypertensives constitute a major group of drugs prescribed due to increasing prevalence of hypertension. This study was conducted on 200 patients, including 95 (47.5\%) males and $105(52.5 \%)$ females. A slight predominance of female population over male population was observed. A study done by Kuchake VG et al, also shows similar predominance of female population in hypertensive cases and literature review reveals that some of studies have reported a higher percentage of hypertension in males. ${ }^{12-14}$ In present study maximum numbers of patients were in the age group of 61-70 years which were 55 (27.5\%) (Table 1).

The antihypertensive drugs prescribed were, calcium channel blockers (CCBs) like amlodipine, nifedipine and clinidipine, beta blockers (BBs) like atenolol, metoprolol 
and labetalol, ACE inhibitors (ACEIs) like enalapril and angiotensin receptor blockers (ARBs) like telmisartan (Table 2). Out of these drugs, the antihypertensive with maximum frequency of use was amlodipine $(78.5 \%)$, followed by atenolol (33.5\%) and enalapril (13.5\%). A study done by Gaikwad B et al, reveals that the most commonly prescribed antihypertensive drug was amlodipine. $^{15}$

This study reveals, maximum number of patients were on single drug therapy accounting for $56.5 \%$, followed by $36.5 \%$ of patients were on two drug therapy and $7 \%$ of patients were on three drug therapy for treatment of hypertension (Table 3). Amlodipine was most frequently used for single drug therapy (37.5\%), the most commonly used drugs in two drug therapy were amlodipine + atenolol $(25.5 \%)$ and the most frequently used drugs for three drug therapy were amlodipine + atenolol + telmisartan $(2.5 \%)$ (Table 4). A similar study done by Bhavika D et al, shows amlodipine was most commonly used in single drug therapy, drugs for two drug therapy included amlodipine + enalapril, followed by amlodipine + atenolol. ${ }^{11}$ Diabetes mellitus $(27.5 \%)$ was the most common co-morbidity seen in study subjects followed by ischemic heart disease $(9.5 \%)$ and cerebrovascular accidents (7\%) (Table 5). Hypertension is one of the contributing risk factors for comorbidities like ischemic heart disease and cerebrovascular accidents.

On assessment of non-antihypertensive drugs used (Table $6)$ shows aspirin $(18 \%)$ was the most frequently prescribed drug, followed by metformin (15\%), atorvastatin (11.5), furosemide $(9.5 \%)$, glimepiride $(8.5 \%)$ and others. That is because these drugs were prescribed to treat the comorbidities.

In present study WHO prescribing indicators were also analysed. The average number of drugs per encounter was $2.38( \pm 1.19)$ per prescription. A study conducted by Bhavika D et al, shows average number of drugs per prescription was as high as 5.64 drugs per prescription. ${ }^{11}$ Present study also shows that, percentage of drugs prescribed by generic name was $76.47 \%$ and $97.89 \%$ of drugs were prescribed from essential drugs list (EDL). Percentage of encounters with an injection prescribed was $4.62 \%$. The drugs given in the form of injections were insulin and others to treat co-morbidities seen in hypertensive patients.

\section{CONCLUSION}

Present study shows the current trends in prescription of antihypertensive drugs at a tertiary care hospital and their rational use. The most common antihypertensive drug used was amlodipine (CCB). The most common combination used for two drug therapy was amlodipine and atenolol $(\mathrm{CCB}$ and $\mathrm{BB})$, and for three drug therapy amlodipine, atenolol and telmisartan (CCB, BB and ARB). There was prevalence of co-morbidities, the most common being diabetes. The average number of drugs per prescription was
$2.38( \pm 1.19)$. Selection of drugs from essential drug list is highly encouraging. Prescribing drugs by generic name needs to be promoted. Study emphasizes need for preventive and educative measures about hypertension in population. Further studies are needed from time to time and in large scale to improve the prescribing pattern in hypertension.

\section{ACKNOWLEDGEMENTS}

Authors would like to thank Dr. Ravi SL, Professor and Head of the Department of Medicine, the faculty and post graduates of Department of Medicine and Dr. Lakshminarayana K, Professor and Head of the Department of Pharmacology, the faculty and post graduates of Department of Pharmacology, Vijayanagar Institute of Medical Sciences, Ballari, Karnataka, India for their kind support and valuable suggestions in completing this study.

\section{Funding: No funding sources Conflict of interest: None declared \\ Ethical approval: The study was approved by the Institutional Ethics Committee}

\section{REFERENCES}

1. Anchala R, Kannuri NK, Pant H, Khan H, Franco OH, Di Angelantonio E, Prabhakaran Det al. Hypertension in India: a systematic review and meta-analysis of prevalence, awareness, and control of hypertension. $\mathbf{J}$ Hypertension. 2014 Jun;32(6):1170.

2. Sharma AK, Dahiya N, Kairi JK, Bharati SM. Prescription patterns of antihypertensive drugs in a tertiary care hospital in India. Int $\mathbf{J}$ Basic Clin Pharmacol. 2017 Jan 20;4(1):55-9.

3. Konwar M, Paul PK, Das S. Prescribing pattern of antihypertensive drugs in essential hypertension in medicine out patients department in a tertiary care hospital. Asia J Pharm Clin Res. 2014;7(2):142-4.

4. Cidda M, Mateti UV, Batchu MK, Martha S. Study of prescribing patterns of antihypertensives in South Indian population. Int J Basic Clin Pharmacol. 2017 Jan 2;3(2):303-7.

5. Bajaj JK, Sood M, Singh SJ, Jerath P. Prescription patterns of antihypertensive drugs and adherence to JNC VII guidelines in a tertiary care hospital in north India. Int J Med Clin Res. 2012;3(2):118-20.

6. WHO. What is drug utilization research and why it is needed? In: Introduction to drug utilization research. World Health Organization. 2003:8-12. Available at: http://apps.who.int/medicinedocs/pdf/s4876e/s4876e. pdf.

7. Dinesh KG, Padmasani L, Vasantha J, Veera RB, Sudhakar P, Uma MR. Drug prescribing pattern among pediatricians in an out-patient department of tertiary care teaching hospital. Indian J Pharm Pract. 2011 Apr;4(2):64-8.

8. Chobanian AV, Bakris GL, Black HR, Cushman WC, Green LA, Izzo Jr JL, et al. The seventh report of the 
joint national committee on prevention, detection, evaluation, and treatment of high blood pressure: the JNC 7 report. JAMA. 2003 May 21;289(19):2560-71.

9. James PA, Oparil S, Carter BL, Cushman WC, Dennison-Himmelfarb C, Handler J, et al. 2014 evidence-based guideline for the management of high blood pressure in adults: report from the panel members appointed to the Eighth Joint National Committee (JNC 8). JAMA. 2014 Feb 5;311(5):50720.

10. National Institute for Health and Care Excellence. Hypertension: clinical management of primary hypertension in adults. CG127. London: National Institute for Health and Care Excellence; 2011.

11. Bhavika D, Prasanna V, Swathi B. Drug utilization study of anti-hypertensive drugs in a tertiary care hospital. International Int $\mathrm{J}$ Basic Clin Pharmacol. 2016;5(4):1580-5.

12. Kuchake VG, Maheshwari OD, Surana SJ, Patil PH, Dighore PN. Prescription pattern of antihypertensive drugs in uncomplicated hypertensive patients at teaching hospital. Indian $\mathbf{J}$ Pharmacy Practice. 2009;2(2).
13. Romday R, Gupta AK, Bhambani P. An assessment of antihypertensive drug prescription patterns and adherence to joint national committee- 8 hypertension treatment guidelines among hypertensive patients attending a tertiary care teaching hospital. Int J Res Med Sci. 2016;4:5125-33.

14. Krishna M, Arif KM, Akalanka D, Manoj KS, Pradeep D, Krishna P. Prescription pattern of anti-hypertensive drugs in adherence to JNC-7 guidelines. Am J Pharmacol Toxicol. 2015;10(1):27-31.

15. Gaikwad B, Bhagat S, Patil K. Comparative assessment of the pattern of anti-hypertensive drugs prescribed in medicine and cardiology outpatient department. Int J Basic Clin Pharmacol. 2016;5(5):1958-65.

Cite this article as: Vishwanath M, Murgesh JV, Arpitha D, Nithiya D. Prospective study on prescribing pattern of antihypertensive drugs at a tertiary care hospital. Int J Basic Clin Pharmacol 2018;7:2126-31. 